\title{
The Chronicles of Long Kesh: Provisional Irish Republican Memoirs and the Contested Memory of the Hunger Strikes ${ }^{1}$
}

\section{Stephen Hopkins}

University of Leicester, UK

\begin{abstract}
This article analyses the recent struggle for control of the Provisional Irish Republican movement's collective memory of the 1980-81 hunger strikes, during which ten Republicans

died. ${ }^{2}$ It proceeds through an examination and interpretation of the published memoir-writing of some of the key protagonists within the broad Irish Republican movement. In particular, it examines the controversy surrounding the allegations made by Richard O'Rawe (former Public Relations Officer for the Irish Republican Army (IRA) prisoners at the time of the 1981 strike), in his two volumes of memoir, Blanketmen (2005), and Afterlives (2010). The article addresses the role of dissent in the movement's collective memory, and the specific role of 'memory entrepreneurs' (Jelin, 2003) in the contestation of the Irish Republican 'official' memory of the hunger strikes.
\end{abstract}

\section{Keywords}

Irish Republicanism, hunger strike, collective memory, memory entrepreneurs, memoirwriting

\section{The Hunger Strikes and Republican Memory: Establishing the 'master narrative'}

The period since the mid-1990s in Northern Ireland has been characterised by the gradual inclusion of the Provisional movement within the structures and institutions of government (Bean, 2007). Since the Belfast (or Good Friday) Agreement of 1998, but particularly since the restoration of devolved government at the Northern Ireland Assembly in 2007, Sinn Féin (SF) has played a central role in stabilising the 'peace process', and is now most decidedly wedded to maintaining its position as a party of government in Northern Ireland. Clearly, the strategic landscape occupied by the Provisional movement is very different from that of the early 1980s, when the IRA was leading an avowedly revolutionary movement, whose 
overriding aim was to overthrow British rule through the use of 'armed struggle'. Then, there was no doubt, either inside the movement or out, that the military instrument was paramount (Smith, 1995). During the 1970s, SF had generally refused to contest elections, with the movement viewing such 'electoralism' with undisguised disdain. For much of this period, many IRA volunteers saw SF as, at best, an auxiliary body which might have some purpose for fund-raising and presenting a public face of the movement; at worst, it was a distraction from the overwhelming priority of building the capacity of the IRA to act as an effective guerrilla army. As President of SF from 1983 until the present day, Gerry Adams has overseen a remarkable process of transition; 'between 1994 and 2004 Sinn Féin moved from the political periphery to the centre-stage...' (McDowell, 2007: 727). Internal critics of the strategic direction of the movement would prefer a term like 'incorporation' to describe this process. Indeed, recognising the potential for such a process to generate disorientation and outright opposition in the ranks of the movement, Adams sought to reassure 'volunteers' that the 'struggle' had not been abandoned, but had instead entered a new phase, requiring new thinking and tactics. The end-goal of Irish unity, however, remained sacrosanct, according to this reading of the historical circumstances (Hopkins, 2009).

At this juncture, therefore, the Republican movement's attitude to its history has become a key site for contemporary political manoeuvring. The movement's culture of memorialisation and its commemorative practices have been placed under the spotlight in a nuanced and complicated fashion. The collective memories of a movement that has for the bulk of its existence been bound up with violent conflict, are clearly marked by both sacrifice, victimhood and suffering, on one hand, but also by questions of legitimacy, responsibility and recognition of hurt on the other. One does not have to subscribe to the view of Conor Cruise O'Brien, namely that within the Republican movement the 'mandate of the dead always outweighs the mandate from the living', to appreciate the 'continuing importance of the dead within Republicanism and the ways in which the dead are linked inexorably to changes within the political landscape and to the political fortunes of Sinn Féin.' (McDowell, 2007: 730). Patterson (2011: 81) has argued that the Provisionals have 'attempted to sanctify current strategies by association with the memory of dead volunteers.' Nowhere is this more evident than in the recent treatment of the memory of the hunger strikes.

It is a commonplace to recognise the key significance of the hunger strikes for the Provisional movement, and their place within the collective memory of the movement has 
been kept burning brightly over the course of the last thirty years. As has been noted in the different, but related, context of communist cultures of memorialisation, there is a pronounced 'tendency to perceive commemorative practices mainly as opportunities for political mobilization.' (Cossu, 2011: 391). This occurred in a double sense: first, in terms of mobilising the movement's members and supporters around contemporary political goals (as defined by the leadership); second, in terms of the socialisation of younger cadres, involving the inter-generational transmission of political and cultural understandings. In the case of the Italian Communist Party's approach to commemoration of the wartime Resistance movement, Cossu argued that the conscious construction and dissemination of partisans' biographies (through the party press, for instance), represented a concerted effort to monopolise and control the important symbolic capital that was attached to the Resistance. This 'extensive use of biography as a peculiar genre of commemoration established continuities within the history of the party: it incorporated the young partisans in a more general and teleological framework of struggle and sacrifice...' (Cossu, 2007: 391). The Irish Republican movement has attempted to use the biographies of the hunger strikers (particularly the 'officer commanding' and first hunger striker to die, Bobby Sands) in a comparable fashion. The Bobby Sands Trust holds the copyright to Sands' prose and poetry writing, and has regularly published selections from these writings, including his diary, One Day in My Life (Sands, 1983, 1997). ${ }^{3}$ However, the strategic goals of this political mobilisation of memory are not fixed, but will change according to the prevailing circumstances (as identified by competing groups, both within and outside the party). The significant point here is that the internal culture of the organisation places constraints upon the production of collective memory, and the strategies used to both propagate and challenge aspects of this memory.

The thirtieth anniversary of the 1981 hunger strike was widely commemorated by SF in 2011. SF organised and engaged in a wide range of commemorative practices, from marches and rallies, through to the production of a special supplement to An Phoblacht (SF's newspaper), as well as branded merchandise. ${ }^{4}$ The continuing centrality of the hunger strikes to the Republican movement's construction of its past is evident; one or two examples should suffice: in 2006, Danny Morrison edited a collection of 'reflections' on the hunger strike, with contributions by a broad range of cultural figures, many of whom were not members of the movement. ${ }^{5}$ The presence of the hunger strike in the contemporary collective consciousness of Republicans, but also many other external sympathisers, is made plain by 
their contributions; as Morrison stated, 'When recalling the 1981 hunger strike, people often preface their memories by saying: "you wouldn't think it was 25 years ago. It seems like only yesterday." Even thirtysomethings who were just 5 or 6 in 1981 have vivid recollections of mass funerals and street rioting...those seven months were of such a magnitude emotionally, historically, politically - that they are seared in the memory. ${ }^{6}$ For Gerry Adams, while the hunger strikes were crucial as a demonstration of the spirit of endurance and resistance of the Republican movement, and the refusal to accept criminalisation by the UK government, nonetheless, this is only one facet of their legacy. The other critical effect of the strikes was to set the Provisional movement on a path that would eventually lead it to the IRA's 1994 ceasefire, and the compromise of the Good Friday Agreement. Writing in the second volume of his memoirs, he argued that the movement needed to move from a 'culture of resistance to a culture of change.' (Adams, 2003: 28). Paradoxically, the hunger strike accelerated the process of constructing such change, even while it confirmed the primacy of resistance at that specific juncture. Although the 'most underdeveloped aspects of our struggle were its politics', and 'within Republicanism, armed struggle was the dominating tendency', Adams was clear that the hunger strikes, and more particularly the electoral victories for protesting prisoners, both north and south ${ }^{7}$, that it helped to create, were by no means 'part of any clever Republican plan or strategy.' (Adams, 2003: 11). However, the argument presented here suggests that the memory of the hunger strikes propagated and validated by the Provisional leadership have most decidedly formed part of a conscious strategy, employed as a crucial element in SF's commemorative practice and contemporary positioning.

Many of those Republicans who are now opponents of the leadership group based around Adams $^{8}$ and Martin McGuinness ${ }^{9}$, and of the policy direction pursued by the movement in the last two decades, are fully in agreement with regards to the heroism and sacrifice of the hunger strikers. ${ }^{10}$ There is also consensus concerning the fact that they were crucial in shaping the subsequent political evolution of the Provisional movement. What remains the subject of bitter contention is whether the direction of such evolution has involved a renunciation of the movement's historic identity and objectives, or whether its essential character remains intact. As Adams recognised, 'not all Republicans were enamoured by the electoral strategy which emerged out of the hunger strike experience. There were those who felt that taking such a course risked turning SF into just another Irish constitutional party and disempowering the Republican struggle, and particularly the armed struggle.' (Adams, 2003: 
15-6). Commemoration of the hunger strikers could thus be understood as double-edged: 'in lauding past republican martyrs there was an inherent risk that the party's [republican] critics would pose the question of whether their sacrifice could be justified in terms of a result that fell far short of basic republican objectives.' (Patterson, 2011: 82; Bean and Hayes, 2001).

Therefore, the contemporary significance of the memorialisation of the hunger strike for the SF leadership is two-fold: first, it wishes to stress the continuity and fidelity of the modern Republican movement with the sacrifice of the hunger strikers, thereby rejecting firmly those ex-members and external observers who accuse the leadership of having reneged on erstwhile political commitments. The 'new phase of the struggle' to unite Ireland does not entail, for the leadership, any profound rupture with the revolutionary past of the movement (Adams 2003: 12). Second, it is also keen to affirm that a key lesson from the strike is that the movement could only hope to achieve its goals by breaking out of its strategic isolation. However, this commitment to an equivalent of the inter-war communist parties' espousal of a 'popular front' approach, to the construction of alliances with external forces, was not easily won. In his study of the popular mobilisation in support of the Republican prisoners' 'five demands ${ }^{11}$, Stuart Ross (2011) makes the important point that in the period 1978-81 the Provisionals were very wary of losing control of the anti-criminalisation movement, which drew in large numbers of non-aligned nationalists and sympathisers (both in Ireland and internationally). The contemporary lesson to be drawn is that the Republican movement could only make progress if it committed itself to 'political outreach' and 'dialogue'. ${ }^{12}$ Securing support from $20-25 \%$ of the electorate in Northern Ireland, and making significant inroads in the Republic are the fruits that SF is reaping from this willingness to engage widely. As Adams put it: 'out of the prison struggle came a revitalised SF, conscious perhaps for the first time of our ability to galvanise public support and to marshal support through elections. The hunger strikes were the beginning of the end of spectatorism in Republican politics.' (Adams, 2003: 49). This end to 'spectatorism' cut both ways, however. Internal opponents of the subsequent direction travelled by the movement were also galvanised by the prison struggle, and they also view themselves as guardians of this collective memory.

\section{A Provisional 'Official Memory' of the Hunger Strikes?}

As Elizabeth Jelin has argued in relation to the production of collective memory, different social actors will produce competing narratives of the past, seeking to establish their 
contemporary legitimacy and power through a privileged connection to that past. There is likely to be a hierarchy of connection to this past, however, with the lived experience of those who were protagonists in historical events carrying most weight, followed by those who have inherited memories of such experience, those who have studied these events closely, and those who are merely external onlookers. In Jelin's argument, agents of the state have a 'central role and special weight because of their power in relation to establishing and developing an "official history/memory."' (Jelin, 2003: 27). The "public management of memory' and the attempt to create an official 'master narrative' for the nation is a crucial facet of state formation. However, a similar effort at shaping the historical narrative may be seen in the memory work of non-state actors. The purpose of such memorialising is to define and reinforce feelings of belonging, with the aim of creating and maintaining social cohesion and defending symbolic borders. In the process, heroes must be mythologised, and their flaws overlooked, in order to present an exemplary or immaculate face to the world. Certain lifestories are held up by political movements as emblematic; they may become 'a personalised form of official party history.' (Morgan, 2005: 56). For Provisional Republicanism, this process can clearly be seen at work in the elevation of Bobby Sands to mythical status, but it can also be seen (more problematically) in the memoirs of Gerry Adams. Alternative potential role models are likely to have their achievements obscured, and their place in the historical record denigrated.

Once these canonical narratives are established as a form of commemorative practice, they often become crystallised and expressed through repetition. However, this process is a dynamic one, and there are subaltern forces that may seek to challenge aspects of the hegemonic master narrative: '[b]ecause the master national narrative tends to be the story of the victors, there will be others who...will offer alternative narratives and meanings of the past, threatening the national consensus that is being imposed.' (Jelin, 2003: 27) For Jelin, whose focus is Latin America, in times of political transition or democratisation from authoritarian rule, there is the possibility that alternative memories (the voices of the marginalised and repressed), that have been too dangerous to articulate beyond the safety of the private world, may be able to emerge into the public sphere: '[p]olitical openings, thaws, liberalisations and transitions, give a boost to activities in the public sphere, so that previously censored narratives and stories can be incorporated and new ones can be generated. Such openings create a setting for new struggles over the meaning of the past...' (Jelin, 2003: 29) What is required to put these alternative counter-narratives into the public 
sphere? According to Jelin, there is a necessity for "memory entrepreneurs" ${ }^{13}$, who she defines as enterprising leaders or social agents who mobilise their energies for a cause they strongly believe in. (Jelin, 2003: 33).

Clearly, the conventional argument could be made that leading Republicans have used their memoir-writing to contest the British government's 'official' narrative of the nature of the prison struggle. Indeed, SF continues to contest the British state's ongoing attempts to maintain the 'criminalisation' of the hunger strikers. This contestation remains a dynamic feature of the memory struggles in Northern Ireland, as can be seen in the protracted and bitter battle to preserve the prison hospital where the hunger strikers died. ${ }^{14}$ However, Bean's characterisation of the recent institutionalisation of the Republican movement, and its evolution in certain areas of Northern Ireland as a 'state-within-a-state', may lead to an extension and refinement of this argument. Controlling the historical narrative and commemorative practice of the movement became of huge practical and symbolic importance. The Provisionals' leadership set about constructing an internally hegemonic 'official' interpretation of their past, even while the broader challenge to the British state's own 'official' memory remained ongoing. The hunger strike was presented to Republicans as a heroic sacrifice, but one which could ultimately be used to legitimise the future direction of the movement's 'line of march'. In Bean's view, 'like a modern representative state, the movement rests on a shifting combination of coercion and consent. In normal periods, power is largely exercised through forms of consent. For both the British state and the Provisionals, consent is preferred to coercion, which is usually the last resort.' (Bean, 2007: 96).

The 'discursive constructions of rupture and continuity' within the Provisional movement meant that an effort to commandeer the collective memory of the hunger strike was a 'dangerous weapon to deploy.' (Graff-McRae, 2010: 217). A small, but growing number of former Provisionals have begun to question aspects of the leadership's 'official' narrative, both with regard to several critical events of the hunger strike itself, and the alleged continuity between the current trajectory of SF and the historical identity of the movement. Some prominent figures, who could properly be described in Jelin's terms as 'memory entrepreneurs' (e.g. Anthony McIntyre, Richard O'Rawe), have been increasingly willing to publicly challenge the leadership's 'master narrative', and they have accused it of being selfjustifying and opportunist. McIntyre, a caustic and implacable critic of Adams' leadership, and the direction pursued since the start of the 'peace process', has been explicit in viewing the specific concerns of some of his erstwhile prison comrades, as part of a much broader 
battle regarding the 'contested authorship of our own history.' (McIntyre, 2008: 104). In his on-line journal The Blanket, as well as several academic contributions, McIntyre has sought to undermine fundamental elements of the leadership's narrative of the 'peace process'. ${ }^{15}$ Socalled 'dissident' Republican organisations (many of whose personnel were once members and activists in the Provisional movement) have been to the fore in attempting to highlight what they view as a 'rupture' in SF's memorialisation of the hunger strike. For example, in contemporary Northern Ireland, Republican Sinn Féin (RSF) has offered unqualified support to protesting dissident prisoners held in Maghaberry jail, contrasting their steadfast and unchanging position on 'political status' for incarcerated Republicans in British jails, with the alleged hypocrisy of the mainstream SF leadership, which has largely distanced itself from the protests. As Frampton (2011: 72) points out, the injunction from dissidents to support these prisoners is couched specifically in terms of 'Remembering the 1981 Hunger strike!': 'such activity was symptomatic of RSF's attempts to take possession of key facets of the Republican heritage...'. The legacy of the hunger strike, and the 'memory work' associated with it, has become a key element in a renewed battle over the 'property of the past' (Cossu, 2011: 387), but this is now centred on the political chasm that exists within Irish Republicanism, rather than between Irish Republicanism and the British state (although the latter struggle is still ongoing, as has been noted). This article argues that a significant, but under-researched, dimension of this battle over memory is to be found in the memoir-writing of key protagonists.

\section{“The Awesome Power of Republican Memory"}

Anthony McIntyre has argued that 2006 ought to have been SF's year. The ninetieth anniversary of the 1916 Easter Rising and the twenty-fifth of the hunger strike 'were destined to merge as one seamless thread of continuous resistance and struggle, and send the party strutting along the stage of Irish nationalism bathed in the light of adulation; the carriers of the eternal flame...It has hardly turned out that way.' (McIntyre, 2008: 105). Instead of 'basking in the reflected glory' of the precious memory of the hunger strike, the SF leadership (and Gerry Adams in particular), faced probing questions from within the movement (but also picked up by the mainstream media) regarding their conduct during 1981 and subsequently. 
The catalyst for this ongoing, and increasingly deep-seated dispute, was the publication in 2005 of a memoir, Blanketmen, by Richard O'Rawe. This article cannot engage in a forensic examination of the claims and counter-claims made by O'Rawe and his antagonists, operating on behalf of the Provisional leadership. To summarise, O'Rawe does not merely accuse the SF leadership of cynically exploiting the memory of the hunger strikers in order to try to justify the contemporary strategy of this group. Instead, he goes much further in speculating that the 'kitchen cabinet' that effectively ran the hunger strike on the 'outside', engaged in prolonging the hunger strike for political gains they believed would accrue. This aspect of O'Rawe's memoir has been vehemently denied by many of those close to the Adams leadership, and several of the key protagonists of the jail dispute (including Brendan 'Bik' McFarlane, the IRA 'Officer commanding' in the jail during the 1981 events, Danny Morrison, and Laurence McKeown, a former hunger striker and co-editor of an oral history of the protest; see Campbell, McKeown and O'Hagan, 1994).

Periodically, since 2005, hostilities have been rejoined. These exchanges have been followed closely in the broad Republican community, and whilst at times it has appeared that a stalemate may have been reached, the controversy shows no sign of either being resolved, or fading in the long-term into the background. ${ }^{17}$ O'Rawe (2010: 160-2) has called for an independent enquiry into the Republican movement's handling of the hunger strike, a sort of internal Republican 'truth commission'. The parallels with Adams' demand for an independent, international truth commission to examine the legacies of the wider conflict are difficult to resist. ${ }^{18}$ However, the SF leadership have shown no enthusiasm for such an approach, and Adams himself has remained 'diplomatically and characteristically silent' on the substance of O'Rawe's allegations. (B. Flynn, 2011: 238).

Those who have resisted the SF leadership's rationalisation for the important departures from Republican orthodoxy that have taken place since the mid-1980s have responded in several ways, including:

1) Attempting to create rival organisational centres, with limited success

2) Retreating into disillusion and apathy

3) Resigning from the Provisionals, but challenging the leadership's historical narrative

O'Rawe is one of those who could see no authentic strategic possibility of reconstructing a renewed IRA campaign based around physical force; indeed, he is not a 'dissident' in the commonly used sense of the term. He has stated unequivocally that 'I support the peace 
process. Like or dislike Gerry Adams, he has to be given credit for ending the unwinnable war.' (cited in McIntyre, 2008: 88). But, he is nonetheless unwilling to leave the battlefield of memory entirely open to what he regards as manipulation and obfuscation. O'Rawe does share with many dissidents a belief that the direction pursued by the SF leadership has traduced core principles of their movement, and dishonestly manipulated the rank-and-file in doing so; his allegations concerning the hunger strike are one more dimension of this more general sense of betrayal, but they touch the rawest nerve of all.

In his two volumes of memoir, O'Rawe has defended the incendiary claim that a secretive leadership group, unbeknownst to the IRA's formal leadership (the Army Council), deliberately maintained the hunger strike between July-October 1981 (after the deaths of four prisoners, but before six others died), despite the fact that the leadership of the prisoners believed a deal was within reach with the British authorities. ${ }^{19}$ Although his motives have been impugned regularly, O'Rawe is not an easy figure to dismiss; he was not a bit-part player in the drama of the hunger strike, and neither did the charge that he was seeking to profit from sensationalising his memoirs carry any weight. O'Rawe's second book, Afterlives (2010) constituted a forensic examination of the positions adopted by Danny Morrison and Brendan McFarlane, on behalf of the leadership, and a defence of the allegations made in Blanketmen. Ultimately, the factual dispute turns around several crucial issues: what was the status of the UK government's 'offer' that all now agree was passed on by the intermediary on July 5 ? Did it constitute something more than an opening gambit in negotiations? Was there something concrete on the table, or at least in the offing? Who would ultimately make the decision regarding whether such an 'offer' was acceptable, and enough to bring the hunger strike to a close? ${ }^{20}$

O'Rawe's decision to publish his first book came after a lengthy period of silence. He presented this as a result of his guilt at permitting himself to acquiesce in what he knew to be a false historical narrative. He also acknowledged his feelings of guilt and inadequacy at not having volunteered for the hunger strike itself, and for not having done more to bring it to an end, even when he believed no more could be achieved. O'Rawe did not spare himself for having taken the line of least resistance, as he saw it; by late July, after he alleges that the outside leadership had effectively vetoed a potential deal, this was his outlook: 'Dead men may have been looking over my shoulder, but live hunger strikers, men who would soon be dead, were effectively looking into my face, and I was turning my head away. I knew in the depths of my being that our cause was lost and I was allowing myself to drift with the 
current. Since that time, I have had to grapple with the terrible knowledge that I personally displayed an appalling degree of moral ambivalence on the issue of the hunger strike. I let my hunger striking comrades down...' (O’Rawe, 2005: 205). Interviewed for the Boston College archive in 2002, O'Rawe broke down, 'as if a dam had finally burst. ${ }^{21}$ O'Rawe determined that he wished to publish his account of the hunger strikes, and although friends and colleagues tried to dissuade him, suspecting correctly that he would be vilified by his former comrades for his pains, nonetheless O'Rawe persevered. He addressed the question of his previous lengthy silence in the prologue of Blanketmen: 'Some may ask why I am writing about these things now? Why did it take twenty-four years for me to tell this story?' (O'Rawe, 2005: no page). His answer is that when he raised his concerns in private with the leadership in 1991, he was told in no uncertain terms that he 'could be shot for opening [his] mouth.' (O’Rawe, 2010: 7). Revealingly, he was still reluctant 'to expose certain individuals in the leadership of the republican movement to the possibility of criticism, while other IRA Volunteers were giving their lives in the same armed struggle for which my ten dead comrades had died.' (O'Rawe, 2005: no page) Alongside the commitment to his jail comrades, O'Rawe also appeared to retain an unshakeable faith in the Republican ideals which lead to the sacrifice of the hunger strikers, even if he came to believe that these ideals had been besmirched in practice, due to the conduct of the Adams group at the time and subsequently. However, like McIntyre, O'Rawe's perception appeared to be that not only was the 'war' over, but that the Republican struggle had been defeated. This clearly put these 'memory entrepreneurs' at odds with the Provisional leadership, both in terms of contemporary political strategy, but also in terms of interpreting the movement's collective memory.

Moreover, the high psychological cost of questioning the mainstream collective memory, and therefore the authority of the leadership, is made plain by O'Rawe. During the maelstrom of the hunger strike era, the overwhelming sense of solidarity of the prisoners, and the intensity of their commitment to each other, and to the cause of fighting against criminalisation, certainly helped to explain the reluctance to pose difficult questions, let alone to break ranks, even privately. During the IRA campaign, many (ex-)Provisionals refused to say or do anything that could give succour to the enemy, through any suggestion of disunity in the Republican ranks. Even after the IRA ceasefire, the very strong bonds of comradeship, and the profound attachment of men like O'Rawe to the Republican 'resistance community', ensured that any embrace of public 'dissidence' from the prevailing 'party memory' was 
hugely problematic. In Jan-Werner Müller's useful distinction, the hunger strike remained a “"communicative memory", that is, living oral memory based on personal recollection' (2002: 13), as opposed to a "cultural memory". ${ }^{22}$ This further reinforced the sense that stepping outside the immensely strong bonds of the Republican 'community of remembrance' that had been forged, would entail an irrevocable rupture. As Brendan Hughes put it, 'people stay quiet out of loyalty to the movement. ${ }^{23}$ Although Hughes effectively supported O'Rawe's accusations in his posthumously published testimony, it is instructive that he also found it enormously difficult to revisit this period, partly due to the emotional trauma of remembering, but also 'because I was a good Republican and....as the old cliché goes, "Stay within the army line, stay within the army lines, don't dissent"...I was still of that calibre when I got released from prison. So I didn’t question.' (Moloney, 2010: 253). This self-censorship has been seized upon by the leadership, so any stance other than backing the orthodoxy of this leadership may be presented as disloyalty.

This unwillingness to contemplate 'thinking outside the movement's structures', and the powerful factors inhibiting Provisionals from venturing down this road, also applied to O'Rawe. One reason for the depth of hostility generated by O'Rawe's memoir concerned the sundering of intimate personal bonds, often forged at times of great trial. As with other dissenting Republicans who have published memoirs (e.g. Eamon Collins [1997], Gerry Bradley [2009]), O'Rawe had been deeply embedded within a dense network of personal relationships, and it was psychologically extremely difficult to imagine being outside this 'closed circle.' One has the impression that he didn't fully understand the depth of the bitterness he would unleash. Indeed, there is some ambivalence on this issue: he 'recognised that by exhuming this particular past, certain republican leaders would bare their teeth. These men, as in 1981, were powerful: they had the authority to bring down on my shoulders the full weight of the republican movement...I knew a chorus of orchestrated indignation and abuse, followed inevitably by character assassination and ostracism, would ensue.' (O'Rawe, 2010: 2). On the other hand, when Anthony McIntyre had tried to warn him of the 'extreme exclusion' he would face, O'Rawe thought to himself: 'deep down, I did not really believe him. Most people think they are good fellows, and I was no different. I would be all right, I thought.' The intensity of emotions that O'Rawe had raised were difficult to appreciate; 'Mackers [McIntyre] went on to say that I had placed a big question mark over the hunger strike, and that that was the "sacred cow", the one issue that hitherto had been untouchable.' (O’Rawe, 2010: 69). Of course, before the definitive entry into a 'post-conflict' environment, 
there were also more prosaic reasons for 'saying nothing' and 'keeping the head down': intimidation, threats and ultimately physical violence were not unknown for those Republicans who refused to follow the 'party line', particularly if they undermined the reputation of the leadership into the bargain. ${ }^{24}$

With the ending of the armed struggle, O'Rawe was finally willing to confront the duplicity that he believed surrounded the hunger strike. However, there was again some ambivalence in O'Rawe's account of his motivation. In 2005, he seemed to attempt to soften the impact of his decision to publish, by insisting he bore "no grudge against the republican movement, or any individual in it' (O'Rawe, 2005: no page). This appeared a product of either naivety or wilful self-deception. He must surely have recognised that his challenge to the established Provisional narrative of the hunger strike, and especially the role of Adams, would be interpreted precisely as a personalised attack, and all of the available evidence suggested that such an attack would not be permitted to pass without serious consequences. If his restated commitment to the movement was designed to forestall the ostracism and character assassination that he suspected was likely to follow, then it was a forlorn hope. ${ }^{25}$

O'Rawe admitted his doubts about aspects of the prison protest, and his opposition to the 'nuclear option' of the hunger strike. Paradoxically, this opposition was shared at the time by Adams, who resisted the prisoners' demands to embark on a second hunger strike in early 1981 because he felt it 'would divert attention and energy from the tasks of political development; it would also undoubtedly prove an extremely draining experience for Republicans; and it might very well result in a substantial, deeply demoralising defeat.' (Adams, 1996: 285). O'Rawe (2005: 83) stated that he had worked hard to stem his foreboding and to dispel the doubts that beset him, by placing his faith in the leadership of the movement on the 'outside': 'I felt I had no alternative but to exorcise these negative thoughts, because they were a challenge to my very soul as a Republican.' Arguably, it was brave (or perhaps foolhardy) of O'Rawe to admit his strong doubts at the time concerning the conduct of not just the prison campaign, but also the 'Long War' strategy more generally; it opened the possibility of the leadership attempting to dismiss his testimony, on the grounds that O'Rawe had always been 'flaky' and unreliable. On the other hand, through his transparent willingness to admit his uncertainties, O'Rawe may have hoped to establish his credentials as an honest witness. 
In his second volume, O'Rawe (2010: 12-3) began by reaffirming that his purpose in publishing his original book was to put right his dead comrades' story, but he also extended his critique of the Adams leadership, arguing from a more explicitly ideological perspective, that this leadership had offered 'little resistance' to British efforts to reinforce the 'unionist veto' through the mechanism of the peace process. In 2005, O'Rawe appeared less obviously as a 'memory entrepreneur' in the mould of McIntyre, but rather as an individual who required, for his own peace of mind, to make a clean breast of a story which had weighed heavily upon him. By 2010, the strength of the leadership-inspired campaign against Blanketmen, and the personal vilification aimed his way, seem to have pushed O'Rawe firmly into the 'dissenters' camp. Perhaps it can also be speculated that the support he had received from McIntyre and others had served to both broaden and deepen O'Rawe's critical stance. For instance, O'Rawe argued that 'the leadership better get used to the idea that this debate is going to expose them... Did you [McIntyre] ever think back then, as we debated socialism and republicanism, that we'd see the day Republicans would be nominating Ian Paisley as First Minister in a Stormont Assembly? Jesus, what a debacle! Bobby Sands, socialist, secularist, republican bears no resemblance to any of this. None of the boys did.' (cited in McIntyre, 2008: 104). In this instance, O'Rawe appeared to go a long way towards claiming Sands and the other 'martyrs' as 'dissidents' avant la lettre.

Alongside this ideological critique of the Republican movement's loss of revolutionary vocation, O'Rawe also used his second volume to examine and expose the true character of the internal organisational culture of the Provisionals. The ethos of military elitism and its emphasis on a strict hierarchy, discipline and 'unity in action', arguably necessary when the movement was a clandestine and conspiratorial organisation, had been carried forward into the 'peace process' era. Yet, this prevailing culture of conformity was never absolute; there were countervailing trends, not least among the 'blanketmen' in Long Kesh. There are two significant ironies here: first, Gerry Adams (along with Brendan Hughes) was one of the moving forces behind the effort to construct a more 'open' culture of 'active Republicanism' in the later 1970s, before he ascended to the leadership. Second, some of the most vociferous and articulate critics of Adams, men such as McIntyre, Tommy McKearney and Tommy Gorman formed their views in the radical and experimental milieu of the H-Blocks. Both the 'dissenters' and Adams are all too aware of this ambivalent internal political culture. O'Rawe's memoir-writing has exposed these tensions once more in stark fashion. The post-peace dissenters have argued that as the Adams leadership has 
progressively abandoned its revolutionary vocation, in favour of an electoralist and reformist agenda, 'it has become much more internally repressive the further it moves away from traditional republicanism and supposedly towards democratic values.' (Gorman cited in McIntyre, 2003: 193).

\section{Conclusion: "Our whole history has been ruined!"}

If it is true that at times of crisis, as Müller (2002: 3-4) has argued, the living are likely to engage in a 'battle for the hearts, minds and souls of the dead', then it is also the case that the dead can appear to be battling for the hearts, minds and souls of the living, as the latter engage in 'a kind of mythical re-enactment of the past.' McDowell (2007: 736) has pointed out that 'convincing its supporters that the sacrifices of those who died for the struggle have not been in vain is imperative to Sinn Féin's continuing success as it moves to the political centre.' However, as this article has demonstrated, a growing number of Provisionals, or former members, have precisely refused to be convinced. These 'memory entrepreneurs' have contested core aspects of the movement's previously hegemonic narrative of the past. The increasingly bitter dispute between O'Rawe, and his small band of supporters, and the mainstream leadership has exemplified the existential issues at stake for Republicans in choosing how to remember the contested past in Northern Ireland, and the critical significance of 'truth-telling' about that past for the contemporary Republican movement and wider community.

After seven years of confronting the leadership, there are few who would question O'Rawe's tenacity, even if many might still argue that his speculation regarding the motivation of the Adams-led 'kitchen cabinet' in 1981 remains unproven. O'Rawe's account has provoked a rupture in what had been a settled collective memory of the hunger strike within the Republican movement, and the leadership-driven 'official' narrative has had considerable doubt cast upon it. Perhaps the key individual who could shed light on these questions is Gerry Adams, but apart from an unrevealing article in An Phoblacht in October 2009 , in which he did not engage directly with the substance of the issues, he has chosen to remain inscrutable about the affair, at least in public. In private, he has met with several of the families of the dead hunger strikers, and has presumably worked hard behind the scenes in an effort to shore up the leadership version. Adams has largely been responsible for shaping what has become the 'official' narrative, but on occasion, there are hints of a more 
nuanced account, and, as is so often the case with memoir-writing, the gaps or lacunae in the story are critical (Foster, 2001: 3; Hopkins, 2007). One example will suffice: in Before the Dawn, Adams (1996: 300) referred to the cumbersome negotiating procedures of the hunger strike 'committee' with the UK government, via the intermediary. He argued that 'there was no mistaking their [UK government] constant efforts to fragment us, to explore weaknesses in our position and to divide us.' However, he makes no mention of the prisoners' conciliatory statement of 4 July (which had been drafted by O'Rawe), nor of the substance of the negotiation in the following hours, before the death of Joe McDonnell, when this round of talks ended. Adams' specific role in this critical aspect of the overall story of the strike is a blank page. Later on in the early 1990s, when the 'back channel' contacts with the UK government were resumed, Adams (2003: 94) stated, 'Martin [McGuinness] and I had been aware of the line of communication since the hunger strike in 1981, although I did not know who was involved or how it worked, and had never asked.' This seems highly implausible.

Adams ended his first volume with an epilogue that now appears distinctly doubleedged: he stated that 'the hunger strike proved to be a watershed in the long struggle between the British state and the Irish movement for national independence. They and their aftermath marked, I believe, the beginning of the end of British rule in Ireland.' (Adams, 1996: 317). Other Republicans continue to argue that this represented instead the beginning of the end to the Provisional movement's challenge to that rule. In offering his support for O'Rawe's willingness to challenge the dominant narrative of the hunger strike within the Republican movement, Anthony McIntyre reveals the destabilising effects on the entire Republican community in this anecdote: 'Listening to a 19-year old woman last evening, born half a decade after the hunger strike, she described the shock to her system [of O'Rawe's allegation] - "Our whole history has been ruined.",26

\footnotetext{
${ }^{1}$ The title is borrowed from Martin Lynch's play of the same name, Chronicles of Long Kesh, (2009). The British government referred to the prison as HMP Maze, whilst prisoners used the older term, Long Kesh.

${ }^{2}$ In this article, the term 'Provisional Republican movement' is used to denote Provisional SF and the Provisional IRA, which operated as a unified movement although with the IRA as 'the senior partner', at least in the period from 1970- 2005, and the 'standing down' of the IRA. For general histories of the Provisional movement, see Patterson (1997), English (2003), and Alonso (2003). Seven of the hunger strikes who died were members of the IRA, whilst three were from the Irish National Liberation Army (INLA).

${ }^{3}$ For a fuller biography of Bobby Sands, see O'Hearn, 2006.
} 
${ }^{4}$ For some republican objections to this 'retail kitsch', see McDonald (2008: 105-8). McDowell (2007: 736 note 4) makes the point that 'the $25^{\text {th }}$ anniversary commemorations which took place in 2006 also generated a significant amount of memory-work, though not to the extent of that which had occurred five years earlier.' In 2001, commemorative practices had included 'a street/road-naming project, a tree-planting initiative and the extensive physical construction of monuments, murals and plaques.' (ibid: 731).

${ }^{5}$ Morrison was a former Publicity Director for SF (1981-90), editor of An Phoblacht/Republican News, and then Secretary of the Bobby Sands Trust. He came to attention outside the Republican movement during the 1981 hunger strike 'when he was nominated by Bobby Sands MP as external spokesman for the fasting prisoners.' (Flackes and Elliott, 1994: 239).

${ }^{6}$ D. Morrison, Daily Ireland, 1 March 2006.

${ }^{7}$ Bobby Sands won the Fermanagh/South Tyrone Westminster by-election caused by the death of sitting MP Frank Maguire in April 1981. Sands stood as an Anti-H Block/Armagh Political Prisoner. After Sands' death on hunger strike on May 5th, Owen Carron, his electoral agent, won the subsequent by-election (after the law was amended to disallow prisoners from standing for election). Gerry Adams incorrectly stated that Carron was elected for SF (Adams, 2003: 14), when in fact SF's prohibition on standing candidates for partitionist assemblies was not removed until the following ard fheis (annual conference). Carron in fact stood as an AntiH Block Proxy Political Prisoner.

${ }^{8}$ For biographies of Adams, see Sharrock and Devenport (1996) and Keena (1990), and for a critique of Adams' memoir-writing, see Hopkins (2009).

${ }^{9}$ McGuinness is currently the SF Deputy First Minister in the Northern Ireland Executive, and has admitted that he was an IRA leader in Derry in the early 1970s. For a critical biography, see Clarke and Johnston (2001).

${ }^{10}$ Of those organised Republican groups opposing the Provisional movement, the most significant have been Republican Sinn Féin (founded in 1986 after a split in the Provisionals, and widely believed to be the political 'wing' of the Continuity IRA), and the 32 County Sovereignty Movement (founded in 1997, and widely believed to be politically close to the Real IRA). Both organisations have consistently proclaimed their fidelity to the memory of the hunger strikers, which has been besmirched by SF; see, for instance, Saoirse and The Sovereign Nation, papers of RSF and 32CSM respectively.

${ }^{11}$ The 'five demands' amounted to the restoration of 'political status' (effectively, prisoner of war status), that had been removed by the British government in 1976. The demands were for the prisoners' right to wear their own clothing, to refuse to engage in prison work, to organise free association with other prisoners, to one visit, letter and parcel each week, and the full restoration of remission lost through the protest. See Clarke (1987), Beresford (1987), McKeown (2001) and Flynn (2011) for further details.

${ }^{12}$ In a review of Ross' book, Eamonn McCann reinforced the argument that 'SF leaders were suspicious of the campaign [in support of the prisoners] from the outset and remained wary throughout.' Belfast Telegraph, 13 January 2012. Tommy Gorman went further, arguing that 'they had to have control and provide political direction, so SF smothered some of the spontaneous social resistance at birth.' (cited in Bean and Hayes, 2001: 89).

${ }^{13}$ Jelin borrows the concept of 'memory entrepreneurs' from Howard Becker's 'moral entrepreneurs'. Henry Rousso has used the similar concept of 'militants of memory', although Jelin (2003: 139, note 9) points out that memory entrepreneurs may be distinguished from 'militants' because they 'generate projects, new ideas, expressions, and creative initiatives - rather than repeating time and again the same script'.

${ }^{14}$ For further discussion of the debate surrounding the site of the jail, and its future, see M.K. Flynn (2011). Another recent example involved the decision by Newry council to name a children's playground after one of the hunger strikers. 
${ }^{15}$ See A. McIntyre $(2008,2003)$ for further details of his critique of the Provisional movement's leadership. The archive of The Blanket is available online at http://indiamond6.ulib.iupui.edu/archives.html. For an interesting comparison of The Blanket and an earlier Irish journal, The Bell see N. Carson and P. Hoey (2012). Mclntyre served 18 years in the Maze/Long Kesh, 4 of them as a 'blanketman' (because the prisoners refused to wear prison uniform, they were left naked apart from wearing blankets; see Coogan, 1980). He also engaged in the 'no wash/no work' protest in the run-up to the hunger strikes. His current blog, The Pensive Quill, is available at http://thepensivequill.am/.

${ }^{16}$ The phrase is taken from A. Mclntyre (2008: 117).

${ }^{17}$ The history of these regular exchanges may be followed in detail on the website, Uncovering the truth about the 1981 hunger strike (http://www.longkesh.info/), which includes statements from the main protagonists, newspaper articles (especially from the Irish News, the main nationalist paper in Northern Ireland) and letters pertaining to the disputed memories of the period.

${ }^{18}$ See G. Adams' article on the subject in An Phoblacht (June 2011: 32). Two of the dead INLA hunger strikers' families (the O'Hara and Devine families) subsequently supported the call for an independent enquiry (Derry Journal, 30 June 2009).

${ }^{19}$ R. O'Rawe (2005; 2010). In his first volume, O'Rawe accused the IRA's ruling Army Council (AC) of taking the fateful decisions regarding the hunger strike, but after discussions with then members of the $A C$, he came to believe that much of the decision-making had, in fact, rested with the 'kitchen cabinet', headed by Adams.

${ }^{20}$ The intermediary between the British government and the Republican movement was known as 'the Mountain Climber', and he has since been identified as Brendan Duddy, a businessman from Derry. O'Rawe (2010: 134-46) provides details of a conference (held in May 2009), in which Duddy confirmed that he had delivered a draft statement by the Secretary of State for Northern Ireland to the republican movement. This was the 'offer' that Danny Morrison took into the jail on July $5^{\text {th }}$, and which $\mathrm{O}^{\prime}$ Rawe argues the jail leadership accepted as the basis for an end to the hunger strike, only to be overruled from outside the jail.

${ }^{21}$ E. Moloney, foreword in R. O'Rawe, (2010: x) Moloney is author of a key text on the development of the Provisionals (2002). In addition, he has overseen the oral history project developed at Boston College, which involved interviews with former paramilitaries, both republican and loyalist (2010).

${ }^{22}$ Müller takes this significant distinction from J. Assmann (2006); see also C. McGrattan (2013).

${ }^{23}$ B. Hughes cited in S. Breen, 'Decommissioned: Provos on scrapheap of history', Sunday Tribune, 16 April 2006. Hughes was a highly significant IRA man in the 1970s and 1980s, and had been 'officer commanding' the IRA prisoners during the first hunger strike in 1980. See also A. McIntyre (2003: 189).

${ }^{24}$ One example of such violence came with the killing of Eamonn Collins in January 1999. He had published a memoir of his growing disillusionment with the movement, in which he was highly critical of Gerry Adams (Collins 1997: 225-6, 231-2). He had also been publicly critical of 'dissident' republicans, and responsibility for his death remains unclear. (McKittrick et al, 1999: 1466-7).

${ }^{25}$ Graffiti referring to O'Rawe as an 'H-Block traitor' appeared near his home in West Belfast (Sunday Times, October 31 2010).

${ }^{26}$ A. Mclntyre, 'A Blanketman still fighting to be heard', Blanket, 4 March 2005.

\section{References}

Adams G (1996) Before the Dawn: An Autobiography. London: Heinemann. 
Adams G (2003) Hope and History: Making Peace in Ireland. Dingle: Brandon.

Alonso R (2007) The IRA and Armed Struggle. London: Routledge.

Assmann J (2006) Religion and Cultural Memory. Stanford: Stanford University Press.

Bean K (2007) The New Politics of Sinn Féin. Liverpool: Liverpool University Press.

Bean K and Hayes M (eds.) (2001) Republican Voices. Monaghan: Seesyu Press.

Beresford D (1987) Ten Men Dead: The Story of the 1981 Irish hunger strike. London: Grafton.

Bradley, G and Feeney B (2009) Insider: Gerry Bradley's Life in the IRA. Dublin: O'Brien Press.

Campbell B, McKeown L and O'Hagan F (eds.) (1994) Nor Meekly Serve My Time: The HBlock Struggle, 1976-1981. Belfast: Beyond the Pale.

Carson N and Hoey P (2012) 'The Bell and The Blanket: Journals of Irish Republican Dissidence', New Hibernia Review 16(1): 75-93.

Clarke L (1987) Broadening the Battlefield: The H-Blocks and the Rise of Sinn Féin. Dublin: Gill and Macmillan.

Clarke L and Johnston K (2001) Martin McGuinness: From Guns to Government. Edinburgh: Mainstream.

Collins E and McGovern M (1997) Killing Rage. London: Granta.

Coogan T P (1980) On the Blanket: The H-Block Story. Dublin: Ward River Press.

Cossu A (2011) 'Commemoration and processes of appropriation: The Italian Communist Party and the Italian Resistance (1943-48)’ Memory Studies 4(4): 386-400.

English R (2003) Armed Struggle: A History of the IRA. London: Macmillan.

Flackes W D and Elliott S (1994) Northern Ireland: A Political Directory, 1968-1993.

Belfast: Blackstaff Press.

Flynn B (2011) Pawns in the Game: Irish Hunger Strikes, 1912-1981. London: Collins Press.

Flynn, M K (2011) 'Decision-making and Contested Heritage in Northern Ireland: The Former Maze Prison/Long Kesh’ Irish Political Studies 26(3): 383-401.

Foster R (2001) The Irish Story: Telling Tales and Making it up in Ireland. London: Allen Lane.

Frampton M (2011) Legion of the Rearguard: Dissident Irish Republicanism. Dublin: Irish Academic Press. 
Graff-McRae R (2010) Remembering and Forgetting 1916: Commemoration and Conflict in Post-Peace Process Ireland. Dublin: Irish Academic Press.

Hopkins S (2007) Fighting without Guns? Political Autobiography in Contemporary Northern Ireland. In Harte L (ed.) Modern Irish Autobiography: Self, Nation and Society. Basingstoke: Palgrave Macmillan.

Hopkins S (2009) 'Comparing Revolutionary Narratives: Irish Republican self-presentation and considerations for the study of communist life-histories' Socialist History 34: 52-69.

Jelin E (2003) State Repression and the Struggles for Memory. London: Latin America Bureau.

Keena C (1990) Gerry Adams: A Biography. Cork and Dublin: Mercier Press.

Lynch M (2010) Chronicles of Long Kesh. London: Oberon Books.

McDonald H (2008) Gunsmoke and Mirrors: How Sinn Féin dressed up defeat as victory. Dublin: Gill and Macmillan.

McDowell S (2007) 'Armalite, the Ballot Box and Memorialization: Sinn Féin and the State in Post-conflict Northern Ireland' The Round Table 96(393): 725-38.

McGrattan C (2013) Memory, Politics and Identity: Haunted by History. Basingstoke: Palgrave Macmillan.

McIntyre, A. (2003) Provisional Republicanism: Internal Politics, Inequities and Modes of Repression. In: F. McGarry (ed.), Republicanism in Modern Ireland. Dublin: University College Dublin Press, 178-98.

McIntyre A (2008) Good Friday: The Death of Irish Republicanism. New York: Ausubo Press.

McKeown L (2001) Out of Time: Irish Republican Prisoners Long Kesh 1972-2000. Belfast: Beyond the Pale.

McKittrick, D, Kelters S, Feeney B and Thornton C (1999) Lost Lives: The stories of the men, women and children who died as a result of the Northern Ireland Troubles. Edinburgh: Mainstream.

Moloney E (2002) A Secret History of the IRA. London: Penguin.

Moloney E (2010) Voices from the Grave: Two Men's War in Ireland. London: Faber and Faber.

Morgan K (2005) An exemplary communist life? Harry Pollitt's Serving My Time in comparative perspective. In: Gottlieb J and Toye R (eds.), Making Reputations: Power, Persuasion and the Individual in British politics London: I.B. Tauris, 56-69. 
Morrison D (ed.) (2006) Hunger Strike: Reflections on the 1981 Hunger Strike. Dingle: Brandon.

Müller J-W (ed.) (2002) Memory and Power in Post-war Europe: Studies in the Presence of the Past. Cambridge: Cambridge University Press.

O’Hearn D (2006) Bobby Sands: Nothing but an Unfinished Song. London: Pluto Press.

O'Rawe R (2005) Blanketmen: An untold story of the H-Block hunger strike Dublin: New Island.

O'Rawe R (2010) Afterlives: The hunger strike and the secret offer that changed Irish history. Dublin: Lilliput.

Patterson H (1997) The Politics of Illusion: A Political History of the IRA. London: Serif.

Patterson H (2011) Beyond the "Micro Group": The Dissident Republican Challenge. In Currie P M and Taylor M (eds.) Dissident Irish Republicanism London and New York:

Continuum.

Ross F S (2011) Smashing H-Block: The Rise and Fall of the Popular Campaign against Criminalization, 1976-1982. Liverpool: Liverpool University Press.

Sands B (1983) One Day in My Life. Cork and Dublin: Mercier Press.

Sands B (1997) Writings from Prison. Dublin: Mercier Press.

Sharrock D and Devenport M (1997) Man of War, Man of Peace? The Unauthorised Biography of Gerry Adams. London: Pan.

Smith M L R (1995) Fighting for Ireland? The Military Strategy of the Irish Republican Movement London: Routledge. 